\title{
MODEL INDIKATOR KINERJA PROYEK PADA SEKTOR BANGUNAN PERUMAHAN BERTINGKAT TINGGI REGIONAL D.K.I. JAKARTA
}

\author{
Andreas Kurniawan Djukardi ${ }^{1}$, Adhiarta Emil Semiawan ${ }^{2}$ \\ ${ }^{1}$ Universitas Pelita Harapan \\ ${ }^{2}$ Universitas Pelita Harapan \\ E-mail: andreas.djukardi@uph.edu
}

\begin{abstract}
Successful projects require an increase in project performance to maintain development aesthetics and productivity. Civil Engineer needs to know the indicators in improving project performance. The research aims to identify key performance indicators that include quality, cost, and time criteria in the contractor's perspective and models of indicators that have a significant influence on the project of regional high-rise residential using Structural Equation Modeling (SEM) - Partial Least methods Square (PLS). The study was used a questionnaire survey. Questionnaires containing performance indicators were developed using a fishbone diagram approach and verified through interviews with experts in construction projects. The result used to determine the level of importance of indicators with the SEM-PLS method. The results show 40 performance indicators identified in the study. All indicators are grouped in 5 criteria, namely: Human Resources, equipment, material, work methods, and finance. The results of the SmartPLS calculation show a model with 18 main indicators that have an influence on project performance on the criteria of cost, quality and time. Three indicators with the highest level of influence are Training of workers on a regular basis, Complying with K3 when working in the field, and Multi-level supervision according to the project organizational structure.
\end{abstract}

Keywords: Indicator, Main performance, SEM-PLS, SmartPLS

\begin{abstract}
ABSTRAK
Proyek yang sukses membutuhkan suatu peningkatan kinerja proyek untuk mempertahankan estetika dan produktifitas pembangunan. Pelaksana proyek perlu mengetahui indikator yang menjadi pusat perhatian dalam peningkatan kinerja proyek. Penelitian bertujuan untuk mengidentifikasi indikator kinerja utama yang meliputi kriteria mutu, biaya, dan waktu dalam perspektif kontraktor dan model dari indikator yang memiliki pengaruh signifikan pada kinerja proyek para kontraktor proyek bangunan perumahan bertingkat tinggi regional dengan menggunakan metode Structural Equation Modeling (SEM) - Partial Least Square (PLS). Penelitian dilakukan dengan mengumpulkan data menggunakan survey kuesioner. Kuesioner yang berisi indikator kinerja, dikembangkan dengan pendekatan diagram fishbone dan diverifikasi melalui wawacara dengan pakar dalam proyek konstruksi. Data yang dihasilkan kemudian digunakan untuk menentukan tingkat kepentingan indikator dengan metode SEM-PLS. Hasil menunjukkan 40 indikator kinerja teridentifkasi dalam penelitian. Seluruh indikator terkelompok dalam 5 kriteria yaitu: Sumber Daya Manusia, peralatan, material, metode kerja, dan finansial. Hasil perhitungan SmartPLS menunjukkan model dengan 18 indikator utama yang memiliki pengaruh terhadap kinerja proyek pada kriteria biaya, mutu dan waktu. Tiga indikator dengan tingkat pengaruh tertinggi adalah Pelatihan pekerja secara berkala, Mentaati K3 (Kesehatan Keselamatan Kerja) saat bekerja di lapangan, dan Supervisi bertingkat sesuai struktur organisasi proyek.
\end{abstract}

Kata kunci: Indikator, kinerja utama, SEM-PLS, SmartPLS 


\section{PENDAHULUAN}

Penyediaan infrastruktur dasar seperti halnya perumahan merupakan salah satu isu strategis dalam Rencana Pembangunan Jangka Menengah Nasional 2015-2019 (Bappenas 2014). Elaborasi lebih jauh dari rencana ini menempatkan pembangunan sektor perumahan merupakan salah satu bagian dari Proyek Strategis Nasional. Provinsi DKI Jakarta adalah salah satu penerima proyek penyediaan hunian layak bagi masyarakat tersebut. Adanya keterbatasan lahan di Jakarta menyebabkan pembangunan gedung baik untuk perumahan, perkantoran dan yang lainnya secara vertikal menjadi suatu pilihan yang relevan. Sehingga di DKI Jakarta, untuk Proyek Strategis Nasional, pembangunan perumahan dilakukan dalam bentuk bangunan bertingkat tinggi/rumah susun (KPPIP 2016).

Agar tujuan mulia pemerintah menyediakan rumah layak huni (rumah susun) untuk masyarakat tercapai, maka proyek-proyek konstruksi bangunan bertingkat tinggi harus dikelola dengan memperhatikan faktor-faktor kesuksesan suatu proyek. Kaming et al (1997) menunjukkan bahwa 11 dari 31 proyek bangunan tingkat tinggi di Indonesia memiliki masalah dalam ketepatan waktu dan keefektifan biaya. Faktor penyebab yang teridentifikasi adalah terjadinya perubahan desain, produktifitas pekerja yang lemah, perencanaan yang kurang, kekurangan sumber daya manusia, kekurangan peralatan, dan kekurangan material. Penelitian lainnya memperlihatkan bahwa hanya 47\% dari proyek bangunan tingkat tinggi di Indonesia yang diselesaikan sesuai jadwal. Sedangkan 15\% dari total proyek diselesaikan ahead schedule (terlalu cepat) dan 38\% dari total proyek diselesaikan behind schedule (terlambat) (Trigunarsyah 2004).

Untuk memastikan keberhasilan proyek, langkah pertama adalah mengidentifikasi apa yang dimaksud dengan keberhasilan suatu proyek dan bagaimana mengukurnya. Keberhasilan suatu proyek dapat didefinisikan sebagai terpenuhinya keperluan-keperluan proyek atau suatu proyek dikatakan berhasil apabila hasilnya lebih baik daripada yang diperkirakan atau dari yang biasa diamati di dalam istilah biaya, jadwal, mutu, keamanan, dan kepuasan para pihak (Ashley et al, 1987). Selanjutnya, suksesnya suatu proyek dapat diidentifikasi dengan mengukur tiga parameter kinerja utama yaitu biaya, waktu dan mutu. Ketiga parameter ini dikenal sebagai 'iron triangle' dan menjadi acuan dari kesuksesan suatu proyek (Chan dan Chan 2004).

Saat ini, dibanding dengan provinsi yang lain, Provinsi DKI Jakarta merupakan merupakan kota yang memiliki jumlah rata-rata bangunan bertingkat paling tinggi dibanding kota lainnya. Lebih jauh lagi, pemerintah juga sedang gencar merencanakan dan melaksanakan proyek-proyek pembangunan. Sehingga agar proyek-proyek menjadi sukses dibutuhkan suatu peningkatan kinerja proyek untuk mempertahankan estetika dan produktifitas pembangunan di DKI Jakarta. Pelaksana proyek perlu mengetahui indikator apa saja yang menjadi pusat perhatian dalam peningkatan kinerja proyek.

Penelitian ini bertujuan untuk mengidentifikasi indikator kinerja utama (key performance indicator, KPI) yang meliputi indikator kriteria mutu, biaya, dan waktu dalam perspektif kontraktor pada proyek bangunan perumahan bertingkat tinggi pada salah satu lokasi di DKI Jakarta. Penelitian ini bertujuan untuk menentukan model dari indikator dengan tingkat pengaruh tertinggi hingga terendah dalam suatu kinerja proyek para kontraktor bangunan perumahan bertingkat dengan menggunakan metode Structural Equation Modeling (SEM) - Partial Least Square (PLS). Hasil penelitian ini diharapkan dapat memberikan suatu gagasan kepada para kontraktor dalam peningkatan kinerja proyek para kontraktor bangunan perumahan bertingkat tinggi regional DKI Jakarta. Peningkatan kinerja proyek yang terjadi karena memprioritaskan kinerja pada indikator-indikator dengan tingkat pengaruh tertinggi dan mengurangi konsentrasi pada peningkatan kinerja proyek pada indikator dengan tingkat pengaruh yang rendah. 


\section{METODE PENELITIAN}

Penelitian ini dilakukan dengan mengumpulkan data menggunakan survey kuesioner yang bertujuan untuk mengumpulkan informasi dan mengeksplorasi struktur yang mendasari suatu proyek dari sisi konteks sosial dan dalam hubungannnya dengan individu dalam konteks tesebut. Survei kuesioner sesuai untuk penelitian ini, karena tujuan penelitian ini adalah untuk mengumpulkan data dari individu-individu dalam industri konstruksi, dengan fokus pada faktor-faktor yang mempengaruhi kinerja proses internal.

Kuesioner yang digunakan, didesain dan dikembangkan dengan pendekatan diagram fishbone dan diverifikasi melalui wawacara dengan pakar dalam proyek konstruksi. Diagram fishbone untuk perumusan indikator dari parameter mutu, biaya dan waktu terdapat pada Gambar 1, 2, dan 3.

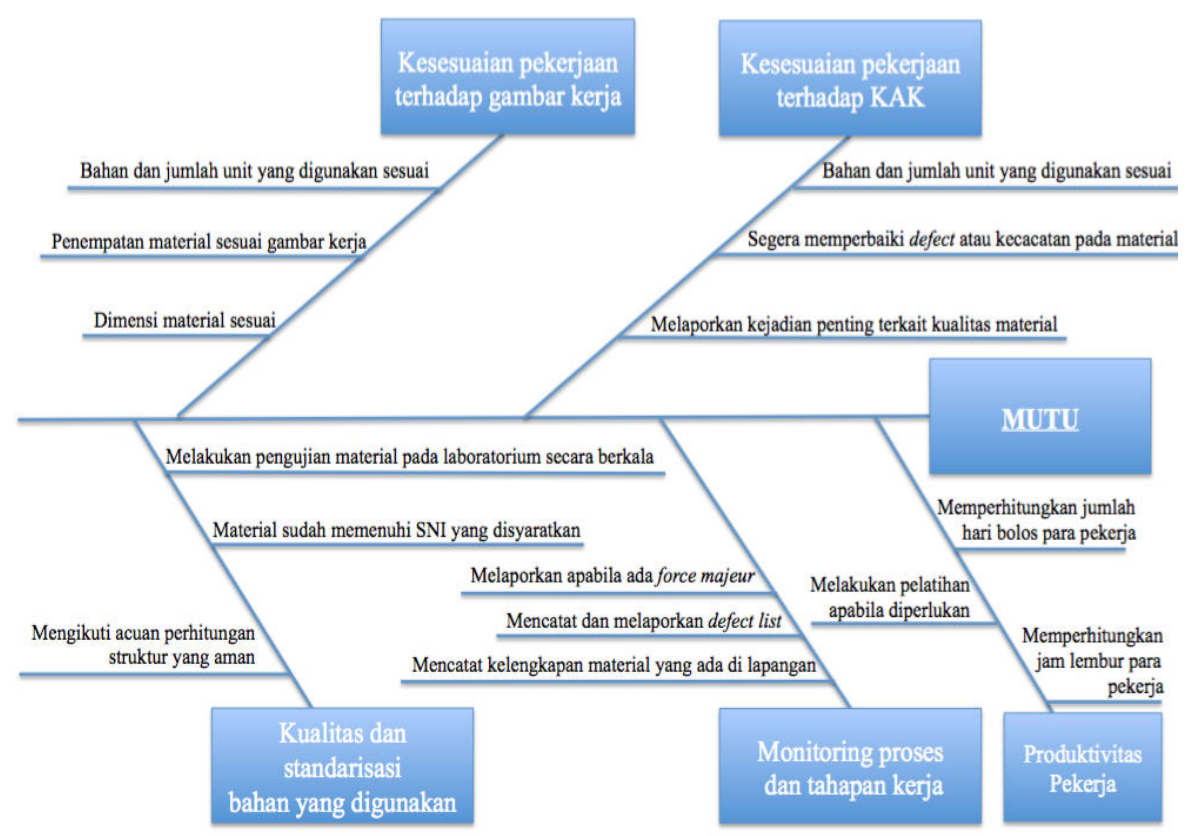

Gambar 1. Diagram Fishbone Hasil Perumusan Untuk Indikator Parameter Mutu

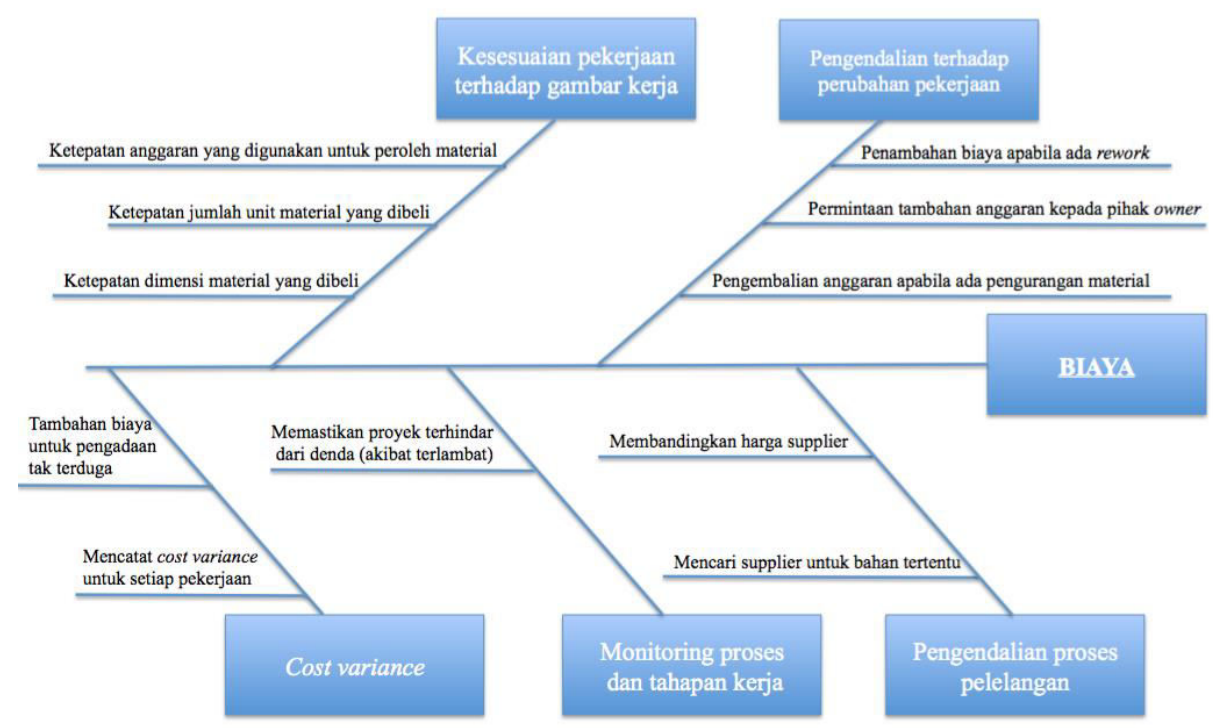

Gambar 2. Diagram Fishbone Hasil Perumusan Untuk Indikator Parameter Biaya 


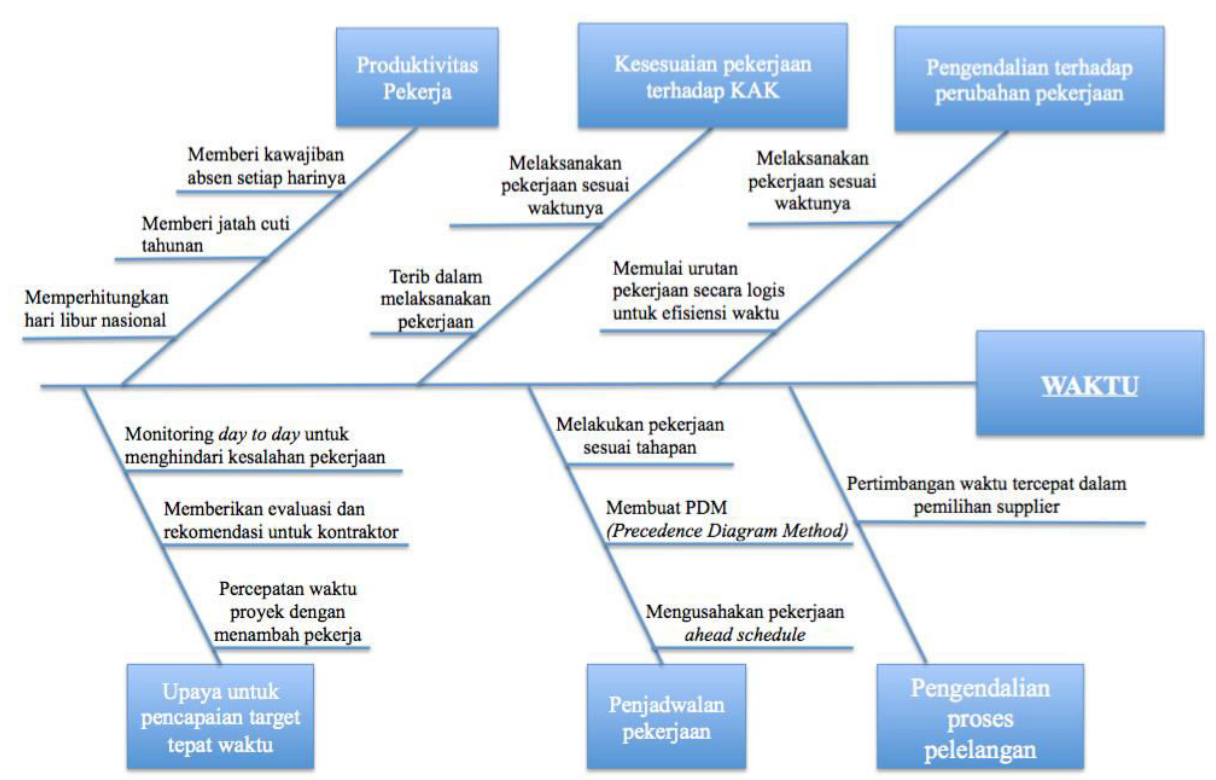

Gambar 3. Diagram Fishbone Hasil Perumusan Untuk Indikator Parameter Waktu

Berikutnya indikator-indikator ini dikelompokkan kedalam 5 kriteria yaitu SDM (Sumber Daya Manusia), Peralatan, Material, Metode Kerja dan Finansial/ Arus kas. Terdapat 40 indikator dalam 5 kriteria yang dinilai bobot kepentingannya oleh responden. Tabulasi lengkap hubungan antara indikator dan kriteria dinyatakan dalam Tabel 1.

Tabel 1. Deskripsi Dari Kriteria Dan Indikator Kinerja

\begin{tabular}{lll}
\hline Kriteria & Kode & Indikator \\
\hline SDM & S1 & Kompetensi pekerja untuk setiap jenis pekerjaan \\
& S2 & Pekerja sanggup untuk mencapai target harian yang ditetapkan dalam waktu \\
& kerja yang sesuai. & \\
& S3 & Pekerja sanggup memprioritaskan pekerjaan yang seharusnya didahulukan. \\
& S4 & Terampil dalam operasional peralatan yang digunakan. \\
& S5 & Pekerja memiliki etos kerja yang baik. \\
& S6 & Komunikasi yang efektif antara Owner, Mandor, Kontraktor, dan Manajemen \\
& S7 & Konstruksi. \\
& S8 & Pelatihan pekerja secara berkala. \\
& S9 & Keselamatan pekerja selama masa konstruksi. \\
& S10 & Mentaati K3 (Kesehatan Keselamatan Kerja) saat bekerja di lapangan. \\
& S11 & Keberadaan Project Manager untuk keberlangsungan proyek. \\
& PAL1 & Ketersediaan semua peralatan penunjan gproyek selama waktu yang \\
& dibutuhkan. & \\
& PAL2 & Penyesuaian peralatan yang digunakan dengan kondisi medan kerja. \\
& PAL3 & Pengecekan secara berkala/pembaruan untuk semua alat. \\
& PAL4 & Produktivitas perlatan dalam penggunaan selama masa konstruksi sehingga \\
& dapat memfasilitasi on time delivery.
\end{tabular}


Tabel 1. Deskripsi Dari Kriteria Dan Indikator Kinerja (Lanjutan)

\begin{tabular}{|c|c|c|}
\hline Kriteria & Kode & Indikator \\
\hline \multirow[t]{6}{*}{ Material } & MT1 & Pengadaan material tepat waktu \\
\hline & MT2 & $\begin{array}{l}\text { Pengiriman material tepat waktu sesuai schedule (tidak menumpuk di lokasi } \\
\text { proyek) }\end{array}$ \\
\hline & MT3 & Kenihilan dalam kecacatan material \\
\hline & MT4 & Pelaksanaan pengujian material di laboratorium secara berkala \\
\hline & MT5 & Kesesuaian syarat dan peraturan yang aktif berlaku terkait spesifikasi material \\
\hline & MT6 & Pemasok material adalah rekanan terpilih \\
\hline \multirow[t]{11}{*}{ Metode Kerja } & MK1 & Mengadakan rapat awal untuk memulai pekerjaan (kick off meeting). \\
\hline & MK2 & Rapi administrasi untuk file internal dan dokumen yang sudah disetujui. \\
\hline & MK3 & $\begin{array}{l}\text { Mengadakan rapat dengan semua pihak terkait dengan kelangsungan proyek } \\
\text { secara berkala. }\end{array}$ \\
\hline & MK4 & Menambah pekerja pada bagian pekerjaan yang under schedule (terlambat). \\
\hline & MK5 & Membuat jadwal kerja yang detil diawal proyek. \\
\hline & MK6 & Gambar kerja acuan sudah melalui tahap approval. \\
\hline & MK7 & Pengadaan material/barang yang sudah melalui tahap approval material. \\
\hline & MK8 & Metode kerja terverifikasi dan mendapat persetujuan. \\
\hline & MK9 & Mengevaluasi instruksi/ teguran dari MK atau Owner terkait pekerjaan. \\
\hline & MK10 & Terdapat metode pengolahan limbah. \\
\hline & MK12 & $\begin{array}{l}\text { Kesiapan dalam membuat tindakan sesuai prosedur jika terjadi force majeur } \\
\text { (gempa bumi, tanah longsor, dll.) }\end{array}$ \\
\hline \multirow{6}{*}{$\begin{array}{l}\text { Finansial/Arus } \\
\text { Kas }\end{array}$} & F1 & Memastikan adanya kesepakatan kontrak kerja. \\
\hline & F2 & Membuat analisa terhadap pengendalian risiko. \\
\hline & F3 & Menyediakan sumber pendanaan untuk kegiatan proyek. \\
\hline & F4 & Menyusun \& memonitor cash flow yang disesuaikan dengan jadwal pekerjaan. \\
\hline & F5 & $\begin{array}{l}\text { Pengendalian biaya sesuai anggaran yang ditetapkan (termasuk kas operasional } \\
\text { harian) }\end{array}$ \\
\hline & F6 & Pertimbangan biaya dalam memilih supplier. \\
\hline
\end{tabular}

Responden menilai tingkat kepentingan dengan skala Likert 1 sampai 5, sebagai berikut (1) Tingkat kepentingan dengan score 5; (2) Tingkat kepentingan dengan score 4; (3) Tingkat kepentingan dengan score 3 (20\%); (4) Tingkat kepentingan dengan score 2 (13\%) dan (5) Tingkat kepentingan dengan score 1 (7\%). Dengan nilai skala yang sama, masing-masing responden juga memberikan penilaian terhadap variabel dependen "Kinerja Proyek" dengan indikator-indikator Biaya, Mutu dan Waktu.

Hasil kuesioner tahap pertama ini digunakan sebagai dalam perhitungan dengan menggunakan metoda Structural Equation Modeling - Partial Least Square (PLS) dan memakai software SmartPLS Langkah-langkah pemodelan dilakukan sebagai berikut:

1. Seluruh variabel dipetakan kedalam SmartPLS sesuai dengan skema pemodelan awal bahwa semua variable independen memiliki nilai atau memberikan pengaruh terhadap variabel dependen. Dari hasil perhitungan dan test reliability dan validity dihilangkan indikator-indikator: F6, M1, M2, MK4, MK1, P1, S1, S11, S2, S4, S6 dengan indikasi nilai Composite Reliability dan Average Variance Estracted ( $A V E$ ) yang rendah. 
Tabel 2. Tabel Data Hasil Kuesioner Dari Responden Terhadap Variabel

\begin{tabular}{|c|c|c|c|c|c|c|c|c|c|c|c|c|c|c|c|c|c|c|c|c|c|c|c|c|c|c|c|c|c|c|c|c|c|c|c|c|c|c|c|c|c|c|c|}
\hline & s1 & & S3 & & & S & & & & $10 \mathrm{~s}$ & & & & & P4 P & P5 PE & & & V2 $\mathrm{M}$ & $13 \mathrm{M}$ & $\mathrm{M} 4 \mathrm{M}$ & M5 ME & $16 \mathrm{Mr}$ & & ИК2 M & МК3 & MK4 & MK5 & MK6 & MK7 & МК8 I & & Мк10 & MK11 & & & & & & & K1MT & K2BY & WT \\
\hline R1 & 5 & & 5 & 5 & 5 & 4 & 5 & 5 & 5 & 5 & 5 & 4 & 5 & 5 & 5 & 5 & 5 & 5 & 5 & 4 & 5 & 3 & 5 & 5 & 5 & 5 & 3 & 5 & 5 & 5 & 5 & 5 & 5 & 5 & 5 & 5 & 5 & 5 & 5 & 4 & 5 & 5 & 5 \\
\hline R2 & 5 & 5 & 4 & 5 & 4 & 4 & 4 & 3 & 5 & 5 & 5 & 4 & 3 & 3 & 3 & 3 & 4 & 5 & 5 & 4 & 4 & 4 & 5 & 5 & 4 & 4 & 5 & 5 & 4 & 2 & 4 & & & 4 & 4 & 4 & 4 & 4 & 4 & 4 & & & \\
\hline R3 & 5 & 4 & 4 & 4 & 4 & 4 & 4 & 4 & 5 & 5 & 4 & 5 & 4 & 5 & 4 & 5 & 4 & 5 & 4 & 4 & 5 & 5 & 4 & 5 & 4 & - & 2 & 4 & 5 & 5 & 5 & & & 4 & 5 & 5 & 5 & 5 & 5 & 5 & & & \\
\hline R4 & 4 & & 5 & 5 & 5 & 5 & 4 & 5 & 5 & 5 & 4 & 5 & 4 & 4 & 4 & 5 & 5 & 4 & 5 & 5 & & 5 & 4 & 4 & 4 & & 5 & 5 & 5 & 5 & 5 & & & 5 & 5 & 5 & 4 & 4 & 4 & 5 & & & \\
\hline R5 & 5 & 4 & 5 & 4 & 4 & 5 & 4 & 4 & 5 & 5 & 4 & 5 & 4 & 4 & 5 & 5 & 5 & 4 & 5 & 4 & 4 & 5 & 5 & 5 & 4 & & 5 & 5 & 5 & 4 & 4 & 4 & & 4 & 5 & 4 & 5 & 4 & 5 & 4 & & & \\
\hline R6 & 4 & & 4 & 5 & 5 & 4 & 5 & 3 & 5 & 5 & 4 & 5 & 4 & 4 & 5 & 4 & 5 & 5 & 5 & 4 & 4 & 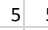 & 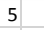 & 5 & 4 & 4 & 5 & 4 & 5 & 5 & 5 & 4 & 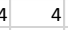 & 4 & 4 & 4 & 4 & 5 & 5 & 5 & & & 5 \\
\hline R7 & 5 & 5 & 5 & 5 & 5 & 5 & 5 & 5 & 5 & 5 & 4 & 5 & 5 & 4 & 5 & 5 & 3 & 5 & 5 & 5 & 3 & 4 & 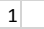 & 5 & 5 & 5 & 3 & 5 & 5 & 5 & 4 & 5 & 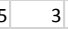 & 3 & 5 & 5 & 5 & 5 & 5 & 5 & 2 & & 5 \\
\hline R8 & 4 & 4 & 4 & 4 & 4 & 5 & 4 & 4 & 5 & 5 & 4 & 4 & 4 & 4 & 4 & 4 & 4 & 5 & 5 & 5 & 5 & 5 & 5 & 4 & 5 & 4 & 4 & 5 & 5 & 5 & 5 & 5 & 5 & 5 & 5 & 5 & 4 & 5 & 5 & 5 & 5 & 5 & \\
\hline R9 & 5 & 4 & 4 & 5 & 5 & 5 & 4 & 3 & 5 & 5 & 4 & 4 & 5 & 4 & 4 & 4 & 5 & 4 & 5 & 4 & 3 & 4 & 4 & 5 & 4 & 4 & 4 & 5 & 5 & 5 & 5 & 4 & 4 & 4 & 5 & 5 & 5 & 5 & 5 & 4 & 4 & 5 & \\
\hline 10 & 5 & 4 & 5 & 5 & 5 & 4 & 5 & 4 & 5 & 5 & 5 & 5 & 4 & 4 & 5 & 5 & 4 & 5 & 5 & 4 & 4 & 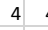 & 4 & 5 & 5 & 4 & 5 & 5 & 5 & 4 & 5 & 4 & - & 5 & 5 & 5 & 5 & 5 & 5 & 5 & & & \\
\hline R11 & 5 & 5 & 5 & 5 & 5 & 5 & 5 & 4 & 5 & 5 & 4 & 5 & 5 & 4 & 5 & 5 & 5 & 5 & 5 & 5 & 4 & 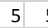 & 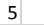 & 5 & 5 & 5 & 5 & 5 & 5 & 5 & 5 & 5 & 5 & 5 & 5 & 5 & 5 & 5 & 5 & 5 & 5 & & \\
\hline R12 & 4 & 5 & 5 & 5 & 5 & 5 & 4 & 4 & 5 & 5 & 5 & 5 & 4 & 5 & 5 & 5 & 4 & 4 & 5 & 4 & 4 & 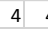 & 4 & 4 & 4 & 4 & 5 & 4 & 4 & 4 & 4 & 4 & & 4 & 4 & 4 & 4 & 5 & 4 & 5 & & & \\
\hline R13 & 4 & 5 & 5 & 5 & 5 & 4 & 5 & 4 & 5 & 5 & 3 & 4 & 4 & 4 & 5 & 5 & 5 & 5 & 5 & 4 & 3 & 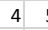 & 5 & 3 & 4 & 3 & 5 & 3 & 4 & 4 & 4 & 4 & 3 & 4 & 5 & 4 & 5 & 5 & 5 & 4 & 4 & & \\
\hline R14 & 5 & 5 & 5 & 5 & 5 & 5 & 4 & 4 & 5 & 4 & 4 & 4 & 5 & 4 & 4 & 4 & 4 & 5 & 4 & 4 & 2 & 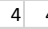 & 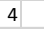 & 5 & 5 & 4 & 3 & 4 & 4 & 4 & 4 & 3 & 2 & 4 & 5 & 4 & 4 & 4 & 5 & 5 & 4 & & \\
\hline 15 & 5 & 5 & 3 & 5 & 4 & 5 & 4 & 5 & 5 & 5 & 4 & 3 & 3 & 3 & 4 & 5 & 5 & 5 & 5 & 5 & 4 & 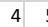 & 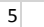 & 5 & 5 & 5 & 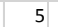 & 5 & 4 & 4 & 5 & & & 5 & 5 & 5 & 4 & 5 & 5 & 5 & 2 & & \\
\hline 16 & 4 & 5 & 4 & 4 & 4 & 5 & 4 & 4 & 5 & 5 & 4 & 4 & 4 & 4 & 4 & 5 & & 5 & 4 & & 4 & 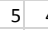 & 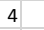 & 5 & 4 & 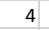 & 5 & 4 & 5 & 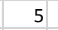 & 4 & & & 4 & 5 & 4 & 5 & 4 & 5 & 4 & & & \\
\hline 17 & 4 & 4 & 5 & 5 & 5 & 4 & 3 & 3 & 5 & 5 & 4 & 4 & 5 & 5 & 5 & 4 & 5 & 5 & 3 & 5 & 5 & 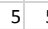 & 5 & 5 & 5 & 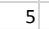 & 2 & 5 & 5 & 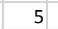 & 5 & & & 3 & 5 & 5 & 5 & 4 & 5 & 4 & 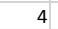 & & \\
\hline 18 & 5 & 4 & 4 & 4 & 4 & 5 & 4 & 5 & 5 & 5 & 5 & 5 & 4 & 4 & 5 & 5 & 5 & 5 & 5 & 5 & 4 & 2 & 2 & 5 & 5 & 5 & 2 & 5 & 5 & & 5 & & & 4 & 5 & 5 & 5 & 5 & 5 & 4 & 5 & & \\
\hline R19 & 4 & 4 & 4 & 4 & 5 & 4 & 4 & 3 & 5 & 5 & 4 & 4 & 4 & 4 & 4 & 5 & 3 & 4 & 4 & 4 & 3 & 3 & 3 & 4 & 4 & 3 & 3 & 3 & 4 & & 4 & 4 & & 4 & 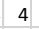 & 4 & 4 & 4 & 3 & 4 & 4 & & \\
\hline 220 & 5 & 4 & 5 & 5 & 5 & 5 & 5 & 5 & 5 & 5 & 5 & 5 & 5 & 5 & 5 & 5 & 3 & 5 & 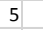 & & & & 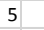 & & 5 & & & 4 & 5 & & 5 & 4 & & 5 & 5 & 5 & 5 & 4 & 5 & 4 & & & \\
\hline R21 & 5 & 4 & 5 & 4 & 4 & 5 & 4 & 5 & 5 & 5 & 5 & 4 & 5 & 5 & 4 & 4 & 4 & 5 & 5 & 2 & 5 & 2 & 4 & 5 & 5 & & & 5 & 5 & & 5 & 5 & 4 & 4 & 5 & 5 & 5 & 4 & 4 & 3 & 5 & & \\
\hline R22 & 5 & 5 & 5 & 4 & 4 & 5 & 3 & 2 & 5 & 4 & 4 & 5 & 3 & 4 & 3 & 3 & 2 & 5 & 4 & 2 & 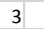 & & 3 & 2 & 4 & 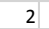 & & 5 & 3 & & 3 & & & 3 & 3 & 2 & 3 & 3 & 3 & 3 & & & \\
\hline R23 & 4 & 4 & 5 & 4 & 4 & 4 & 5 & 4 & 5 & 5 & 4 & 5 & 5 & 5 & 4 & 5 & 4 & 4 & 4 & 5 & 4 & 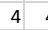 & 4 & 5 & 4 & & & 5 & 5 & & 5 & & & 4 & 4 & 5 & 4 & 4 & 4 & 5 & & & \\
\hline R24 & 5 & 4 & 2 & 5 & 4 & 5 & 4 & 2 & 5 & 4 & 4 & 4 & 1 & 4 & 3 & 4 & 3 & 5 & 5 & 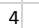 & 3 & 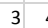 & 4 & 3 & 4 & 4 & 3 & 3 & 5 & & 3 & 4 & & 3 & 5 & 4 & 5 & 4 & 4 & 4 & 4 & & \\
\hline R25 & 4 & 5 & 5 & 4 & 3 & 4 & 5 & 3 & 5 & 4 & 5 & 4 & 4 & 3 & 3 & 3 & 4 & 4 & 4 & 4 & 4 & 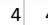 & 4 & 4 & 3 & 5 & 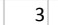 & 4 & 5 & & 4 & 4 & & 4 & 4 & 4 & 5 & 5 & 4 & 3 & 4 & & \\
\hline 26 & 5 & 5 & 5 & 5 & 5 & 5 & 4 & 4 & 5 & 5 & 5 & 5 & 4 & 5 & 5 & 5 & 5 & 5 & 4 & 5 & 5 & 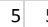 & 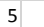 & 5 & 5 & & & 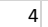 & 5 & & & & & 4 & 5 & 4 & 5 & 5 & 5 & 4 & & & \\
\hline R27 & 5 & 4 & 4 & 4 & 4 & 5 & 4 & 3 & 5 & 5 & 3 & 5 & 4 & 4 & 5 & 4 & 4 & 5 & 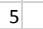 & 5 & 4 & 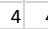 & 4 & 4 & 5 & 2 & 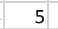 & 5 & 5 & & & 5 & & 4 & 5 & 5 & 5 & 4 & 5 & 3 & 4 & 4 & \\
\hline 28 & 4 & 4 & 4 & 4 & 5 & 5 & 3 & 3 & 5 & 5 & 3 & 3 & 4 & 5 & 4 & 5 & 4 & 5 & 5 & 4 & 4 & 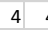 & 4 & 4 & 4 & 3 & 2 & 4 & 4 & 2 & 4 & 5 & & 4 & 5 & 3 & 4 & 5 & 5 & 5 & 4 & 4 & \\
\hline 29 & 5 & 5 & 4 & 4 & 5 & 4 & 4 & 5 & 5 & 5 & 3 & 4 & 5 & 4 & 5 & 5 & 5 & 5 & 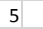 & 4 & 5 & 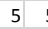 & 5 & 5 & 5 & 4 & 5 & 5 & 5 & 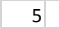 & 4 & 4 & 4 & 4 & 4 & 4 & 4 & 4 & 5 & 5 & 4 & 4 & \\
\hline R30 & 5 & 4 & 4 & 5 & 3 & 3 & 3 & 2 & 4 & 4 & 3 & 5 & 4 & 5 & 4 & 5 & 3 & 4 & 4 & 5 & 5 & 5 & 4 & & 4 & 5 & 2 & 5 & 5 & 9 & 4 & 5 & & 4 & 5 & 5 & 2 & 4 & 5 & 5 & 4 & & \\
\hline 231 & 2 & & 4 & 4 & 5 & 5 & 4 & 4 & 5 & 5 & 4 & 4 & 5 & 5 & 4 & 5 & 5 & 4 & 5 & 5 & 4 & 2 & 4 & 4 & & 4 & & 5 & & & 4 & 4 & 4 & 5 & 5 & 5 & 4 & 5 & 4 & 4 & 4 & & \\
\hline 32 & 5 & & 5 & 3 & 5 & 4 & 4 & 4 & 4 & 4 & 5 & 4 & 4 & 4 & 3 & 4 & 5 & 4 & 4 & 4 & 3 & 4 & 2 & 5 & 5 & 5 & & 5 & 4 & & 5 & 5 & 3 & 4 & 5 & 4 & 5 & 5 & 5 & 5 & 4 & 5 & \\
\hline
\end{tabular}

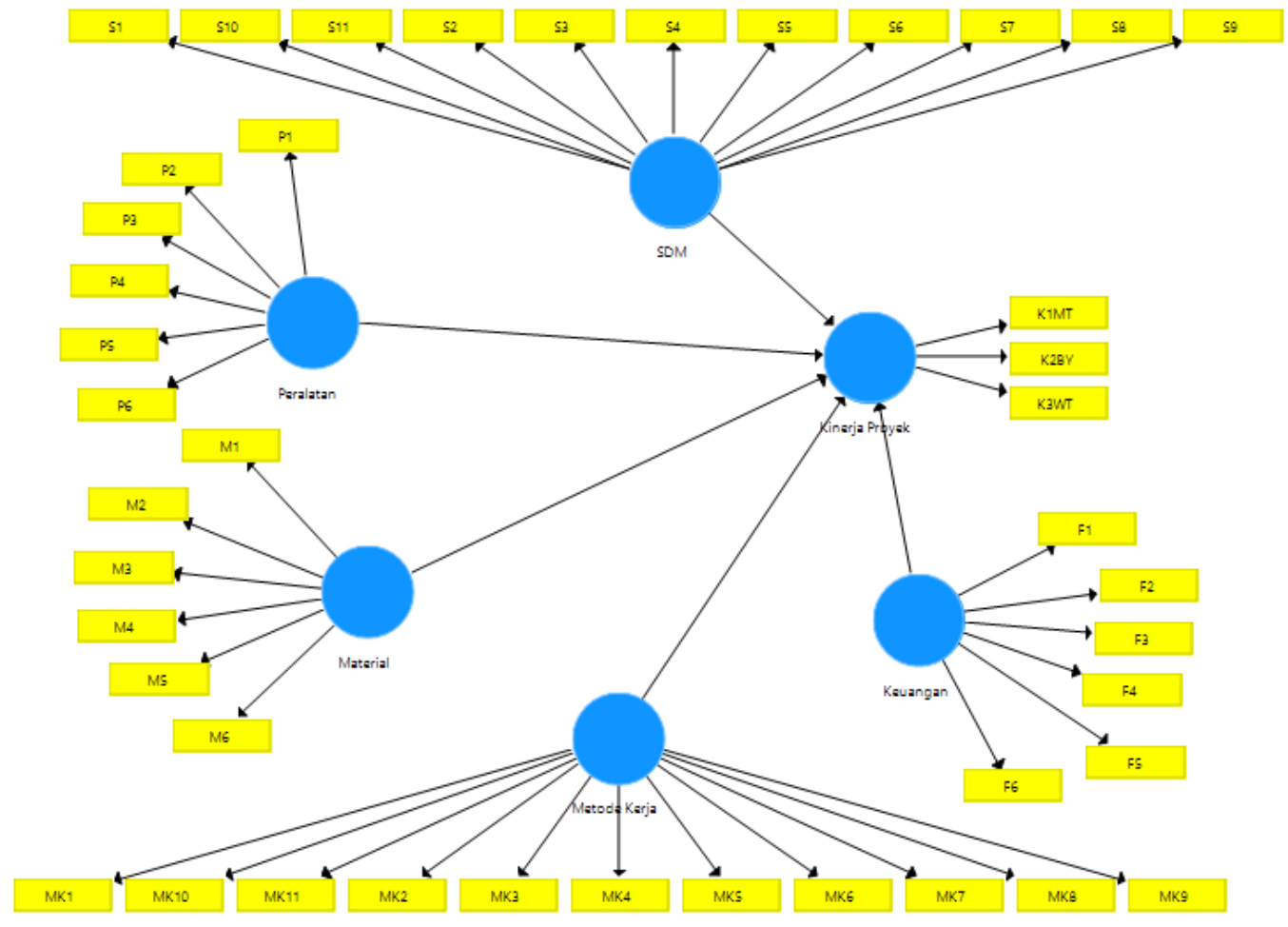

Gambar 4. Pemodelan Awal SmartPLS 
2. Pengurangan variabel pada skema tahap awal kembali dihitung dengan SmartPLS untuk mendapatkan model yang sesungguhnya. Dan apabila nilai Composite Reliability dan Average Variance Estracted (AVE) masih rendah akan dilakukan pengurangan kembali. Hal ini dilakukan sampai nilai CR dan AVE terindikasi baik.
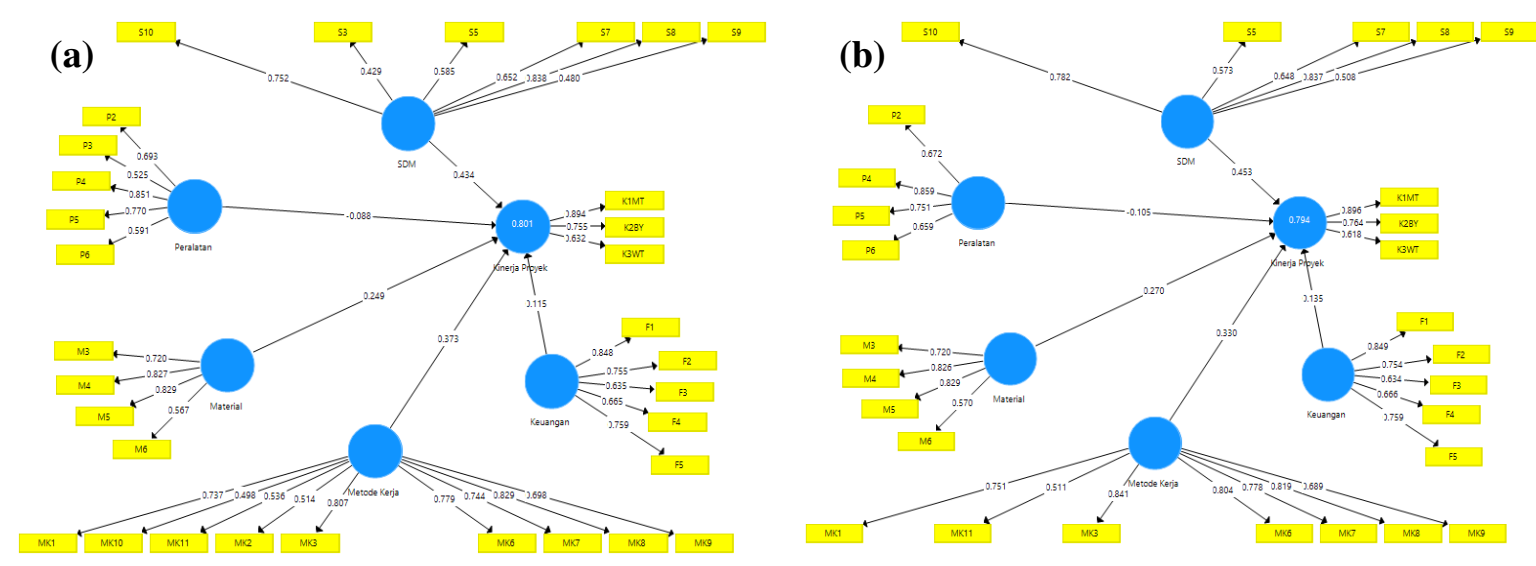

Gambar 5. (a) Tahap 2; (b) Tahap 3 Pemodelan SmartPLS
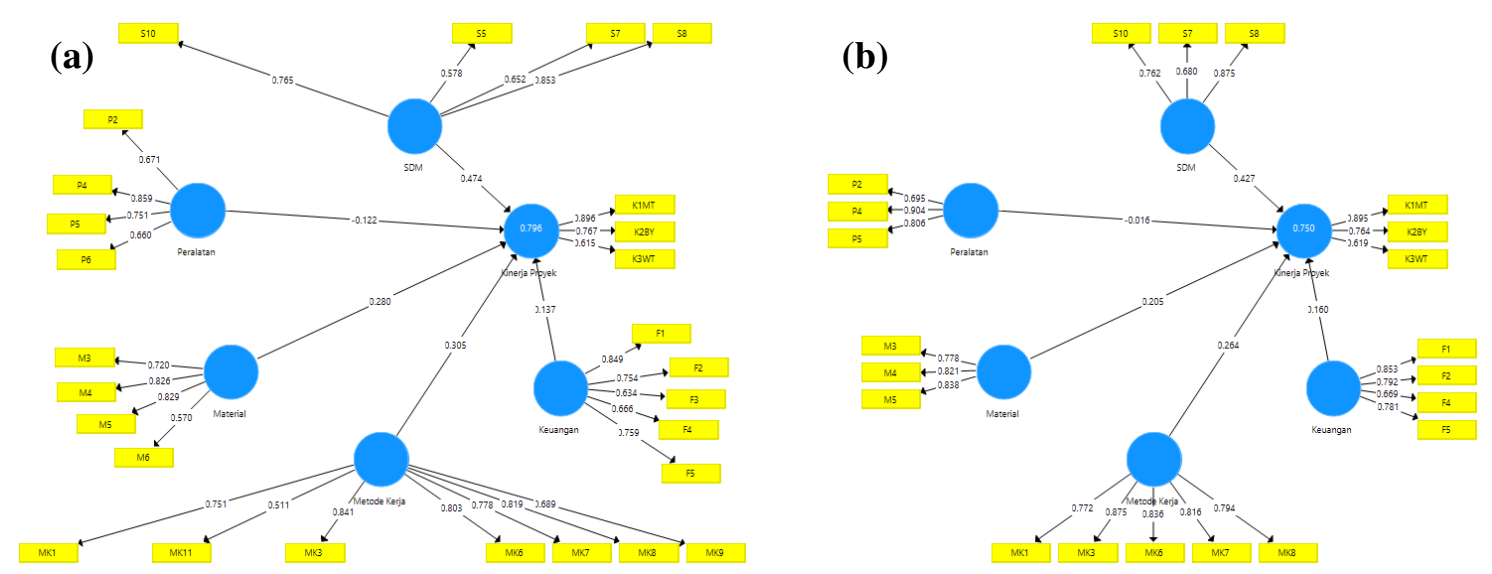

Gambar 6. (a) Tahap 4; (b) Final Pemodelan SmartPLS

\section{HASIL DAN PEMBAHASAN}

Untuk mendapatkan pemodelan kinerja proyek dari perspektif kontraktor pada bangunan perumahan pada salah satu lokasi rumah susun di Jakarta, dalam penelitian ini telah dicoba menentukan tingkat kepentingan indikator dimensi mutu, biaya, dan waktu yang digunakan sebagai template atau dasar penilaian terhadap kontraktor.

Pada tahap awal penentuan model kinerja proyek pada proyek rusun ini terindikasi 40 variabel independen dan 3 variabel dependen sebagai tolak ukur awal. Dengan penggunaan metode Structural Equation Modeling - Partial Least Square (PLS) dibantu dengan piranti lunak SmartPLS 3.2.7. Hasil akhir dari pemodelan ini adalah 18 variabel independen yang mempengaruhi variabel dependen dalam variabel mutu, biaya serta waktu. 


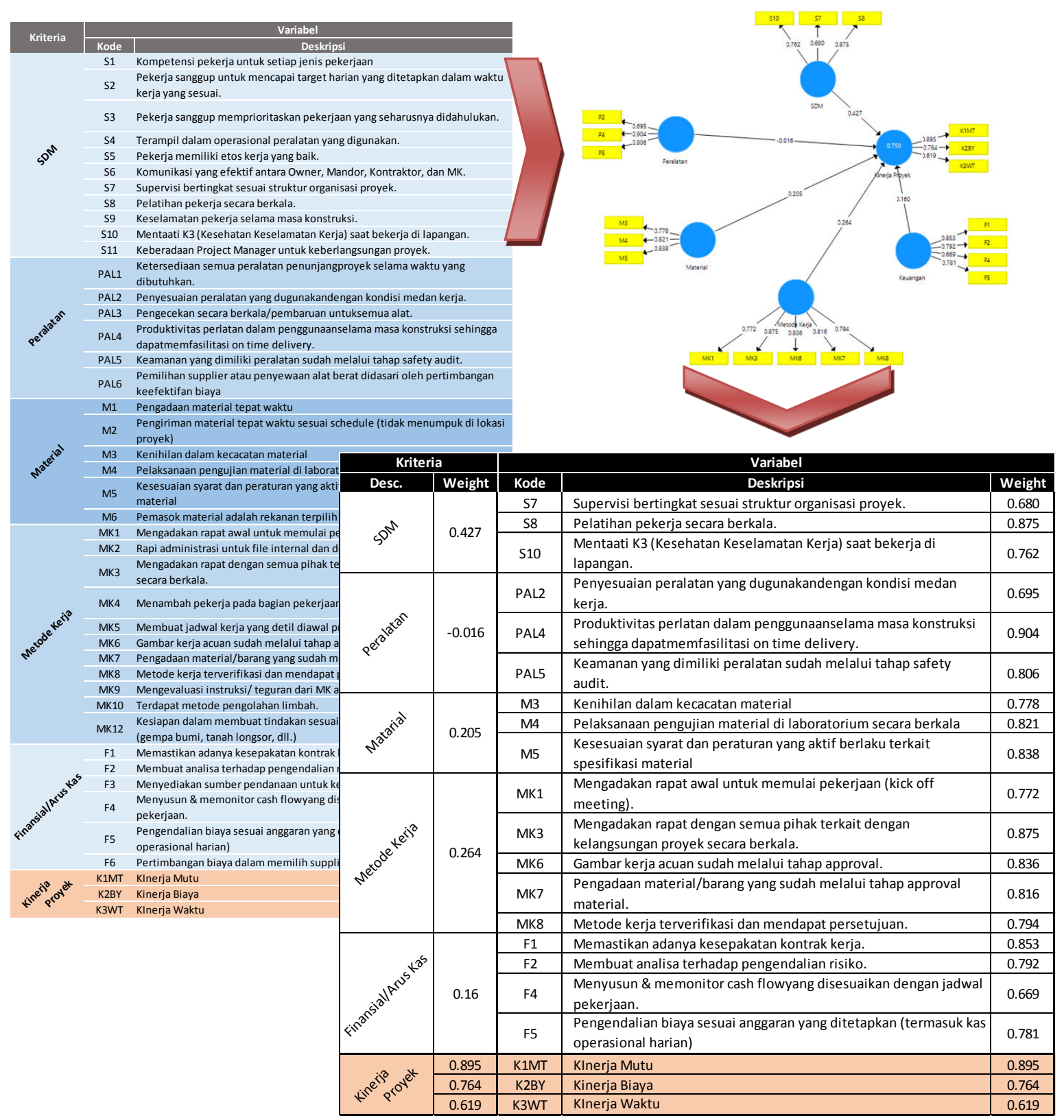

Gambar 7. Proses Dan Hasil SmartPLS

Memiliki bobot 0.427 , Sumber Daya Manusia (SDM) menjadi kriteria utama yang memberikan paling banyak pengaruh positif terhadap kinerja proyek rusun ini. Seluruh variabel didalam kriteria SDM ini juga merupakan 3 variable teratas dengan bobot tertinggi. Hal ini menjelaskan bahwa memang dalam proyek ini, kinerja yang diukur dalam bentuk mutu, biaya dan waktu sangat tergantung kepada sumber daya manusia yang mengerjakannya. Pelatihan secara berkala dan kontinu, awareness terhadap $\mathrm{K} 3$, dan supervisi memberikan dampak pengaruh yang significan terhadap kinerja proyek secara keseluruhan. Tingginya pengaruh dari variabel ini dapat dipahami karena memang hasil pekerjaan dari seorang pekerja akan dapat terlihat langsung dan memiliki efek yang bersifat langsung mempengaruhi mutu.

Pengaruh negatif dari tingginya pengaruh dari kritreria SDM dapat diatasi dengan penggunaan alat bantu kerja atau peralatan, bahkan otomasisasi dari pekerjaan-pekerjaan yang dilakukan manusia sudah menjadi hal yang biasa pada saat ini, terlebih pada dunia konstruksi. Dalam penelitian ini 
peralatan justru memiliki pengaruh negatif walaupun hanya memberikan kontribusi kecil, dapat diartikan bahwa semakin banyak penggunaan alat bantu kerja justru menurunkan kinerja. Namun apabila dihubungkan dengan variabel S8 yang merupakan variable paling memiliki pengaruh yang besar, pengaruh negatif dari alat bantu kerja ini menjadi jelas, bahwa kompetensi dari SDM atau operator dari alat bantu juga memiliki peranan yang penting.

Tabel 3. Peringkat Dari Variabel Kinerja Proyek

\begin{tabular}{|c|c|c|c|}
\hline Peringkat & & Variabel & Weight \\
\hline 1 & S8 & Pelatihan pekerja secara berkala. & 0.37 \\
\hline 2 & S10 & $\begin{array}{l}\text { Mentaati K3 (Kesehatan Keselamatan Kerja) saat bekerja di } \\
\text { lapangan. }\end{array}$ & 0.33 \\
\hline 3 & S7 & Supervisi bertingkat sesuai struktur organisasi proyek. & 0.29 \\
\hline 4 & MK3 & $\begin{array}{l}\text { Mengadakan rapat dengan semua pihak terkait dengan } \\
\text { kelangsungan proyek secara berkala. }\end{array}$ & 0.23 \\
\hline 5 & MK6 & Gambar kerja acuan sudah melalui tahap approval. & 0.22 \\
\hline 6 & MK7 & $\begin{array}{l}\text { Pengadaan material/barang yang sudah melalui tahap approval } \\
\text { material. }\end{array}$ & 0.22 \\
\hline 7 & MK8 & Metode kerja terverifikasi dan mendapat persetujuan. & 0.21 \\
\hline 8 & MK1 & $\begin{array}{l}\text { Mengadakan rapat awal untuk memulai pekerjaan (kick off } \\
\text { meeting). }\end{array}$ & 0.20 \\
\hline 9 & M5 & $\begin{array}{l}\text { Kesesuaian syarat dan peraturan yang aktif berlaku terkait } \\
\text { spesifikasi material }\end{array}$ & 0.17 \\
\hline 10 & M4 & Pelaksanaan pengujian material di laboratorium secara berkala & 0.17 \\
\hline 11 & M3 & Kenihilan dalam kecacatan material & 0.16 \\
\hline 12 & F1 & Memastikan adanya kesepakatan kontrak kerja. & 0.14 \\
\hline 13 & F2 & Membuat analisa terhadap pengendalian risiko. & 0.13 \\
\hline 14 & F5 & $\begin{array}{l}\text { Pengendalian biaya sesuai anggaran yang ditetapkan (termasuk kas } \\
\text { operasional harian) }\end{array}$ & 0.12 \\
\hline 15 & F4 & $\begin{array}{l}\text { Menyusun \& memonitor cash flow yang disesuaikan dengan } \\
\text { jadwal pekerjaan. }\end{array}$ & 0.11 \\
\hline 16 & PAL2 & $\begin{array}{l}\text { Penyesuaian peralatan yang digunakan dengan kondisi medan } \\
\text { kerja. }\end{array}$ & $(0.01)$ \\
\hline 17 & PAL5 & $\begin{array}{l}\text { Keamanan yang dimiliki peralatan sudah melalui tahap safety } \\
\text { audit. }\end{array}$ & $(0.01)$ \\
\hline 18 & PAL4 & $\begin{array}{l}\text { Produktivitas perlatan dalam penggunaan selama masa konstruksi } \\
\text { sehingga dapat memfasilitasi on time delivery. }\end{array}$ & $(0.01)$ \\
\hline
\end{tabular}

Pada kriteria metode kerja, intisari dari 5 variable yang memberikan pengaruh pada kinerja proyek adalah komunikasi serta persetujuan dari rencana kerja dan metode pelaksanaan mempunyai peran yang tidak kecil. Komunikasi dan persetujuan ini adalah kunci dari pelaksanaan pekerjaan-perkerjaan pada proyek-proyek konstruksi bangunan karena memberikan kejelasan pada langkah pelaksanaan dalam menjalankan proyek.

Material dan Finansial merupakan dua kriteria yang memiliki bobot yang relatif sama dalam pengaruhnya terhadap kinerja dari proyek kontruksi. Material memang memiliki dampak langsung pada hasil pekerjaan, sehingga mendapatkan material yang sesuai dengan spesifikasi, baik dari ketentuan proyek dan syarat-syarat dari standar yang berlaku, adalah hal yang utama pada kriteria Material. Sedangkan pada kriteria finansial, kepastian akan pekerjaan yang tertuang dalam bentuk kontrak merupakan pengaruh yang paling besar pada kriteria ini. 


\section{KESIMPULAN DAN SARAN}

Model indikator kinerja proyek pada bangunan perumahan bertingkat tinggi dengan fokus pada proyek rusun pada salah satu lokasi di DKI Jakarta, dari perspektif kontraktor dapat di gambarkan sebagai berikut:

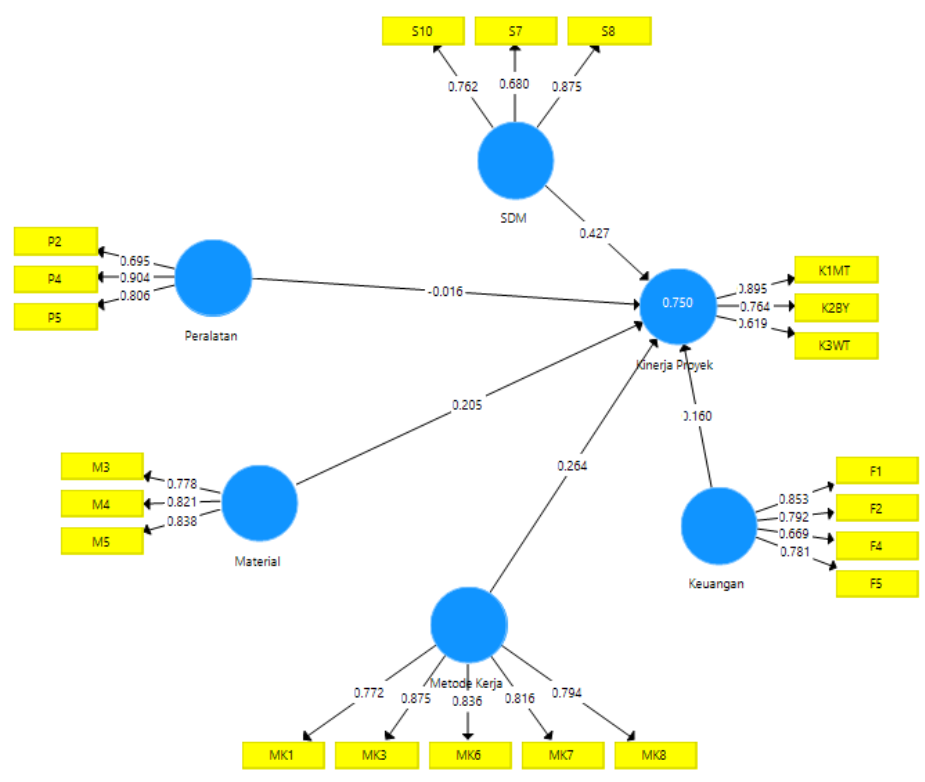

Implikasi potensial dari penelitian ini dapat digunakan untuk meningkatkan kinerja proyek dengan cara menentukan tingkat kepentingan indikator dimensi mutu, biaya, dan waktu yang dapat digunakan sebagai template atau dasar penilaian terhadap kontraktor. Hasilnya akan menjadi strategi dalam peningkatan kinerja proyek dari perspektif kontraktor pada bangunan perumahan bertingkat tinggi regional DKI Jakarta dengan memprioritaskan kinerja pada indikator-indikator dengan tingkat kepentingan tertinggi dan mengurangi konsentrasi pada peningkatan kinerja proyek pada indikator dengan tingkat kepentingan yang rendah.

\section{DAFTAR PUSTAKA}

[1] Ashley, D.B., Lurie, C.S. and Jaselskis, E.J. (1987). Determinants Of Construction Project Success. Project Management Journal, 18 : 69-79

[2] [BAPPENAS]. (2014). Prioritas Kedaulatan Energi Dan Infrastruktur RPJMN 2015 - 2019. https://bappenas.go.id/index.php/download_file/view/16611/4981/. [15 Februari 2018].

[3] Chan, A.P.C., Chan, A.P.L. (2004). Key Performance Indicators For Measuring Construction Success. Benchmarking, $11:$ 203-221.

[4] [KPPIP]. (2016). Proyek Strategis Nasional - Sektor Perumahan. https://kppip.go.id/proyekstrategis-nasional/e-sektor-perumahan/ . [15 Februari 2018]

[5] Kaming, P.F., Olomolaiye, P.O., Holt, G.D., Harris, F.C. (1997). Factors Influencing Construction Time And Cost Overruns On High-Rise Projects In Indonesia. Construction Management and Economics, 15 : 83-94.

[6] Lindhard, S., Larsen, J.K. (2016). Identifying The Key Process Factors Affecting Project Performance. Engineering, Construction and Architectural Management, 23 : 657-673

[7] Trigunarsyah, B. (2004). Constructability practices among construction contractors in Indonesia. Journal of Construction Engineering and Management, 130 : 656-669. 